\title{
Oral Manifestations of Systemic Diseases
}

Editor

JOEL J. NAPEÑAS

\section{ATLAS OF THE ORAL AND MAXILLOFACIAL SURGERY CLINICS OF NORTH AMERICA}

www.oralmaxsurgeryatlas.theclinics.com

Consulting Editor

RICHARD H. HAUG

September 2017 • Volume 25 - Number 2 